\title{
IMMUNISATION AGAINST HSV-1 KERATITIS WITH A SYNTHETIC gD PEPTIDE
}

\author{
A. HEILIGENHAUS ${ }^{1}$, P. A. WELLS ${ }^{2}$ and C. S. FOSTER ${ }^{3}$ \\ Boston, Massachusetts
}

\begin{abstract}
SUMMARY
The authors tested the protective efficacy of, and the immune response to, immunisation with a synthetic peptide of glycoprotein D (gD) of $\mathrm{HSV}-1$ in a murine model of herpes stromal keratitis (HSK). HSV-1 susceptible $\mathbf{A} / \mathbf{J}$ mice were immunised subcutaneously with a peptide corresponding to the $\mathbf{N}$-terminal epitope gD(5-23) prior to corneal HSV-1 challenge. Divergent immunisation protocols were compared for their protective potency, their ability to prevent the establishment of latency in the trigeminal ganglion, and their effect on the immune system. Low dosages $(31 \mu \mathrm{g})$ of gD(5-23) protected against encephalitis and HSK. Protective efficacy was higher when $\mathrm{gD}(5-23)$ was coupled to the carrier protein keyhole limpet haemocyanin (KLH) and was emulsified with adjuvant. Latent infection was found in all control mice but in only $50-75 \%$ of immunised mice. The most potent protection was correlated with anti-HSV-1 neutralising antibodies of $\operatorname{IgG}_{1}$ and $\operatorname{IgG}_{2 a}$ isotypes, but free gD(5-23) protected in the absence of anti-HSV-1 antibodies. Our results suggest that immunisation with gD(5-23) stimulates both humoral and cellular immune mechanisms which protect against HSV-1 keratitis.
\end{abstract}

Recurrent herpes simplex keratitis is a major cause of blindness in developed countries. ${ }^{1}$ The destruction of corneal architecture results from reactivation of the herpes virus and the associated host inflammatory responses. Currently available anti-viral drugs are potent inhibitors of active HSV-1 replication but are not capable of preventing and eliminating latent HSV-1 infection. ${ }^{2}$ Vaccination strategies for protection against herpetic ocular disease and latency have

From: ${ }^{1}$ Department of Ophthalmology, University of Essen, Essen, Germany; ${ }^{2}$ Upjohn Company, Kalamazoo, Michigan, USA; ${ }^{3}$ Department of Ophthalmology, Hilles Immunology Laboratory, Harvard Medical School, Boston, Massachusetts, USA.

Correspondence to: Dr C. Stephen Foster, FACS, Department of Ophthalmology, Massachusetts Eye and Ear Infirmary, Harvard Medical School, 243 Charles Street, Boston, MA 02114, USA. been explored for nearly three decades. ${ }^{3-8}$ Passive immunisation with monoclonal antibodies to herpes simplex virus glycoproteins ${ }^{9-11}$ has rekindled interest in polyvalent, subunit and recombinant vaccines for protection against HSV-1.

Subunit vaccines consisting of purified HSV-1 envelope glycoproteins were effective in protecting animals against subsequent HSV-1 challenge when given prior to corneal HSV-1 inoculation. ${ }^{12,13} \mathrm{HSV}$ glycoprotein $\mathrm{D}(\mathrm{gD})$ is one of the dominant immunogens among the envelope glycoproteins of HSV. It plays an essential role in the attachment of HSV to the plasma membrane of cells and is critical to viral penetration into the cell. ${ }^{14}$ Furthermore, gD has a profound influence on both the humoral and cellular immune responses to HSV-1. ${ }^{15}$ We have previously shown that mice immunised subcutaneously with live HSV-1 virus or UV-inactivated virus are protected against keratitis and encephalitis. ${ }^{16} \mathrm{We}$ showed that immunisation with purified $\mathrm{gD}$ is effective in protecting animals against herpes simplex stromal keratitis, ${ }^{17}$ and these findings were subsequently confirmed by others. ${ }^{18}$

Eisenberg et al. ${ }^{19}$ showed that vaccinotherapy using synthetic peptides corresponding to the amino $(\mathrm{N})$ terminal amino acid residues $1-23$ of $\mathrm{gD}$ [gD(1-23)] or $\mathrm{gD}(8-23)$ protected mice against an intraperitoneal or footpad challenge. ${ }^{19}$ In the study reported here we investigated the influence of subcutaneous immunisation with $\mathrm{gD}(5-23)$ in a murine model of herpes simplex stromal keratitis. We tested the ability of this peptide to confer protection against herpes stromal keratitis and latent infection of the trigeminal ganglion. We compared divergent immunisation protocols for their protective potency and effect on the immune system.

\section{MATERIALS AND METHODS}

Mice

Male and female $\mathrm{A} / \mathrm{J}$ mice $\left(\mathrm{IgH}-1^{\mathrm{e}}, \mathrm{H}-2^{\mathrm{a}}\right)$ were obtained from the Jackson Laboratory (Bar Harbor, 
Table I. Protocols for the subcutaneous immunisation of $\mathrm{A} / \mathrm{J}$ mice with glycoprotein $\mathrm{D}$ and the $\mathrm{N}$-terminal 5 -23 amino acid residues of glycoprotein D prior to corneal HSV-1 inoculation

\begin{tabular}{|c|c|c|}
\hline Injection day -35 & Injection day -21 & Injection day -7 \\
\hline - & PBS. CFA & PBS. CFA \\
\hline $3 \mu \mathrm{ggD} . \mathrm{CFA}$ & $1.5 \mu \mathrm{ggD}$. CFA & $1.5 \mu \mathrm{g} \mathrm{gD}$. CFA \\
\hline - & $31 \mu \mathrm{g} \mathrm{gD}(5-23)$. CFA & $31 \mu \mathrm{g} \mathrm{gD}(5-23)$. CFA \\
\hline - & $31 \mu \mathrm{g} \mathrm{gD}(5-23)-\mathrm{KLH}$. CFA & $31 \mu \mathrm{g} g \mathrm{D}(5-23)-\mathrm{KLH}$. CFA \\
\hline - & $31 \mu \mathrm{g} g D(5-23)-K L H . P B S$ & $31 \mu \mathrm{g} g D(5-23)-K L H$. PBS \\
\hline
\end{tabular}

PBS. phosphate-buffered saline: CFA. complete Freund's adjuvant: KLH. keyhole limpet haemocyanin: gD. glycoprotein D of HSV-1: $\mathrm{gD}(5-23)$, synthetic peptide corresponding to the N-terminal sequence 5-23 of glycoprotein D of HSV-1.

ME). All mice were 6-8 weeks old. Previous studies have demonstrated that this strain is highly susceptible to developing herpes simplex stromal keratitis. ${ }^{17.20}$ Use and animal housing conformed with the ARVO guidelines on the Use of Animals in Ophthalmic and Vision Research and the NIH Guide for the Care and Use of Laboratory Animals.

\section{Virus}

HSV-1 (F strain) stocks were kindly provided by Dr Priscilla Shaffer (Harvard Medical School. Boston. MA). They were passed on Vero cell monolayers (American Type Culture Collection. Rockville. MD) and suspended in minimal essential medium (MEM: Gibco, Grand Island. NY) in all experiments.

\section{Inoculation}

Mice were anaesthetised intraperitoneally with ketamine hydrochloride $2 \mathrm{mg}$ (Ketalar. ParkeDavis, Morris Plains. NJ) and xylazine $400 \mu \mathrm{g}$ (Rompun, Mobay, Shawnee. KA). The right cornea was scratched 8 times in a criss-cross pattern using a 25 gauge needle, and virus solution was instilled into the cul-de-sac. ${ }^{20}$ Optimal virus dilutions for inducing stromal keratitis were determined in preliminary experiments, and $5 \mu \mathrm{l}$ containing $6 \times 10^{3} \mathrm{PFU}$ of HSV-1 ( $F$ strain) were instilled.

\section{Synthetic Peptide, Glycoprotein D}

$\mathrm{gD}(5-23)^{1.5}$ with an additional cysteine residue at the carboxylterminus of the peptide was synthesised by Biosearch (San Rafael, CA). The peptide sequence is 5N-Ala-Asp-Ala-Ser-Leu-Lys-Met-Ala-Asp-Pro-Asn-ArgPhe-Arg-Gly-Lys-Asp-Leu-Pro-23-cysteine. The carboxylterminus of the peptide was covalently coupled to the carrier protein keyhole limpet haemocyanin (KLH; Pierce, Rockford, IL) by employing $N$-succinimidyl bromoacetate (Behring Diagnostics. San Diego. CA), as described by Bernatowicz and Matsueda.21 Briefly, KLH was bromoacetylated with $\mathrm{N}$-succinimidyl bromoacetate and then separated from excess reagent by gel filtration with G-25 columns (Pharmacia. Piscataway. NJ). Bromoacetylated KLH was then reacted with excess cysteine containing synthetic peptide. followed by gel filtration chromatography. The coupling efficacy was assessed by assaying for $S$-carboxymethylcysteine residues. ${ }^{22}$

HSV-1 gD was purified from Vero cells infected with HSV-1 (KOS) by passing detergent extracts of the cells over Sepharose 4B columns containing immobilised monoclonal antibodies directed against $\mathrm{gD} .^{23.24}$ Bound $\mathrm{gD}$ was eluted with $3 \mathrm{M}$ sodium thiocyanate and analysed for purity using sodium dodecyl sulphate polyacrylamide gel electrophoresis. 25

\section{Vaccination Protocols}

We compared five different immunisation protocols in the present study (Table I). All five groups of $\mathrm{A} / \mathrm{J}$ mice were injected subcutaneously. In all groups, the right cornea was challenged with HSV-1 1 week after the last injection. The peptide. gD or control vehicle (phosphate-buffered saline: PBS) was emulsified in complete Freund's adjuvant (200 $\mu$ l per mouse) for groups 1-4; group 5 was immunised without adjuvant.

\section{Clinical Scoring}

The inoculated eyes were examined every other day for 14 days following HSV infection using a binocular surgical microscope. The development of herpetic blepharitis. epithelial keratitis, stromal keratitis and encephalitis was scored in masked fashion, grading each on a scale of $(0$ to $4+$, as previously described in detail. $^{10.20}$

\section{Histopathology}

The inoculated eyes were removed on day 14 postinfection and fixed in Karnovsky's fixative (1\% paraformaldehyde and $1.25 \%$ glutaraldehyde in $0.2 \mathrm{M}$ sodium cacodylate buffer. $\mathrm{pH}$ 7.2). After rinsing with PBS, the eyes were dehydrated through ascending ethanol concentrations, embedded in LKB Historesin (LKB Producter AB. Bromma. Sweden). sectioned at $2 \mu \mathrm{m}$ with a Sorvall JB-4 microtome, and stained with haematoxylin and eosin.

\section{Serum Neutralising Antibody Activity}

Serum was pooled from 5 mice just prior to corneal inoculation with HSV-1. Serial twofold dilutions were incubated with $8 \times 10^{2}$ PFU of HSV-1 (F strain) for $30 \mathrm{~min}$ at $37^{\circ} \mathrm{C}$. Serum-virus mixtures were then incubated on Vero cell monolayers for $60 \mathrm{~min}$ at $37^{\circ} \mathrm{C}$ in Eagle`s MEM (Gibco), containing Earle's. salts (Gibco). 10\% fetal calf serum (Gibco), penicillin $100 \mathrm{U} / \mathrm{ml}$ (Gibco), streptomycin $100 \mu \mathrm{g} / \mathrm{ml}$ (Gibco). 
Fungizone $2.5 \mu \mathrm{g} / \mathrm{ml}$ (Flow Laboratories, McLean, VA), L-glutamine $2 \mathrm{mM}$ (Gibco) and $0.1 \%$ pooled human IgG (Gammar, Armour Pharmaceutical, NJ). The virus neutralising titres are the highest serum dilution that produced a $50 \%$ reduction in plaque number relative to control monolayers incubated with virus alone. ${ }^{26}$

Enzyme-linked Immunosorbent Assay (ELISA) for Anti-HSV-1 Antibodies

An indirect ELISA technique was performed. ${ }^{27}$ Briefly, $100 \mu$ l of a 1:50 dilution of HSV-1 (F) in carbonate buffer $\mathrm{pH} 9.6$ were added to each well of 96 well plates (Linbro Titertec, Flow Laboratories) and incubated overnight at $4{ }^{\circ} \mathrm{C}$. The wells were washed with PBS-Tween buffer then blocked with a 1:20 dilution of normal goat serum for $90 \mathrm{~min}$ at $37^{\circ} \mathrm{C}$. Following additional washes, serial twofold dilutions of pooled serum samples, harvested from 5 mice per group at the time of HSV infection, were added to the wells and incubated for $90 \mathrm{~min}$ at $37^{\circ} \mathrm{C}$. Control wells were incubated with pooled serum samples collected from normal, non-immunised mice. The wells were washed and then incubated with 1:2000 dilutions of peroxidase-conjugated goat antimouse $\operatorname{IgG}_{1}, \quad \operatorname{IgG}_{2 \mathrm{a}}, \quad \mathrm{IgG}_{2 \mathrm{~b}}$ or $\mathrm{IgG}_{3}$ (Southern Biotechnology Associates, Birmingham, AL) for 90 min at $37^{\circ} \mathrm{C}$. After washing, orthophenylenediamine substrate solution (Sigma, St Louis, MO) was added and incubated for $30 \mathrm{~min}$ at $20^{\circ} \mathrm{C}$. The reaction was stopped with sulphuric acid and the optical density read at $492 \mathrm{~nm}$ using a TiterTek Multiscan spectrophotometer (Flow Laboratories). Serum dilutions with an optical density at least twice that of control wells were considered positive for anti-HSV antibodies.

\section{Latent Ganglionic HSV-1 Infection}

On day 14 after corneal inoculation mice were killed by cervical dislocation and the trigeminal ganglia ipsilateral to the inoculated cornea were removed under sterile conditions, as previously described. ${ }^{28}$ Since immediate mincing reduces the viral shedding, ${ }^{29}$ we incubated the explanted ganglia. The ganglia were placed on Vero cell monolayers in 24 well plates (Falcon, Lincoln Park, NY) with $1 \mathrm{ml}$ MEM containing $5 \%$ fetal calf serum, $2 \mathrm{mM} \mathrm{L-}$ glutamine, penicillin $100 \mathrm{U} / \mathrm{ml}$ and streptomycin 100 $\mu \mathrm{g} / \mathrm{ml}$ (all from Gibco) and incubated at $37^{\circ} \mathrm{C}$ in a humidified atmosphere with $5 \% \mathrm{CO}_{2}$ for 3 weeks. The control wells on each plate contained uninfected Vero cell monolayers. The co-cultures were observed for cytopathological effects daily using inverted phase microscopy. Results of preliminary experiments and of our prior work in this model ${ }^{29}$ demonstrated that homogenised ganglia were negative for cytopathic effect on Vero cell monolayers for
21 days, showing the functional latency of this model and the lack of infectious virus in the ganglia at 14 days after corneal inoculation.

\section{Statistics}

Chi-squared analysis was used to analyse the significance of differences between the groups for the incidence of herpes simplex keratitis and the establishment of latent infection. The significance of differences in the means of the clinical scoring, virus neutralising titres and anti-HSV titres was determined by Fisher's protected test for least significant difference.

\section{RESULTS}

Protective Efficacy of $g D(5-23)$ Against Herpetic Keratitis

Subcutaneous injection of $\mathrm{gD}(5-23)$ or $\mathrm{gD}$ of HSV-1 prior to corneal infection with HSV-1 $(\mathrm{F})$ reduced the incidence $(p<0.05)$ and severity $(p<0.0001)$ of herpes simplex keratitis in A/J mice (Table II, Fig. 1). As shown in Table II, 12 of $15 \mathrm{~A} / \mathrm{J}$ mice injected with PBS,CFA developed stromal keratitis, confirming our previous findings in naive $\mathrm{A} / \mathrm{J}$ mice. ${ }^{17,20}$ Only 4 of $16 \mathrm{~A} / \mathrm{J}$ mice injected with $\mathrm{gD}$ prior to corneal HSV-1 infection developed stromal keratitis. The best protection against stromal keratitis was observed when mice were injected with $\mathrm{gD}(5-23)$ coupled to $\mathrm{KLH}$ and emulsified with adjuvant $(p<0.05)$. However, $\mathrm{gD}(5-23)$ had a protective capacity even when not coupled to this carrier protein, or when given without adjuvant (Table II, Fig. 1). The protection against ocular herpetic disease and encephalitis was similar when $\mathrm{A} / \mathrm{J}$ mice were boosted twice using the same dosage of $\mathrm{gD}(5-23)$ (data not shown).

$\mathrm{A} / \mathrm{J}$ mice injected with either $\mathrm{gD}(5-23)$ or $\mathrm{gD}$ were completely protected against encephalitis, whereas $20 \%$ of the mice developed encephalitis when sham immunised $(p<0.05$, Table II).

\section{Histopathology}

The corneas of herpes stromal keratitis susceptible $\mathrm{A} / \mathrm{J}$ mice injected with $\mathrm{gD}(5-23)$ had a normal appearance by day 14 after infection. Only a few mononuclear cells were found in the corneoscleral limbus, while neutrophils were completely absent. In

Table II. A/J mice were immunised as described in Materials and Methods. Animals were followed for 2 weeks after inoculation with HSV-1 for signs of stromal keratitis and encephalitis. The table indicates the number of mice with more than $1+$ stromal haze or with encephalitis

\begin{tabular}{lcc}
\hline Groups of A/J mice & Stromal keratitis & Encephalitis \\
\hline PBS, CFA & $12 / 15$ & $3 / 15$ \\
Glycoprotein D, CFA & $4 / 16$ & $0 / 16$ \\
gD(5-23), CFA & $5 / 16$ & $0 / 16$ \\
gD(5-23)-KLH, CFA & $1 / 15$ & $0 / 15$ \\
gD(5-23)-KLH, PBS & $4 / 16$ & $0 / 16$ \\
\hline
\end{tabular}

Abbreviations as in Table I. 
Table III. Virus neutralising titre in serum harvested from immunised $\mathrm{A} / \mathrm{J}$ mice at the time of corneal infection with $\mathrm{HSV}-1$. The titre is expressed as the highest dilution of antiserum which produced a $50 \%$ reduction in plaque number. as calculated from the means of plaques counted in samples

\begin{tabular}{lcc}
\hline Groups of A/J mice & No. of mice & Virus neutralising titre \\
\hline PBS, CFA & 3 & 0 \\
gD, CFA & 6 & $1 / 100$ \\
gD(5-23), CFA & 6 & 0 \\
gD(5-23)-KLH, CFA & 6 & $1 / 100$ \\
gD(5-23)-KLH, PBS & 6 & $1 / 25$ \\
\hline
\end{tabular}

Abbreviations as in Table $\mathrm{I}$.

contrast, $\mathrm{A} / \mathrm{J}$ mice injected with the control vehicle had a marked accumulation of mononuclear cells and neutrophils in the limbus and in the cornea. The cornea was markedly oedematous, exhibiting a profound proliferation of fibrovascular tissue which was infiltrated with inflammatory cells (Fig. 2).

\section{Anti-HSV-1 Neutralising Antibody Titres}

Anti-HSV-1 sera collected from A/J mice immunised with different injection protocols were tested for virus neutralisation (Table III). The neutralising titre from $\mathrm{A} / \mathrm{J}$ mice injected with $\mathrm{gD}$ was $1 / 100$. The titres in mice injected with $\mathrm{gD}(5-23)-\mathrm{KLH}$ were higher in those mice which received adjuvant $(p<0.01)$. The free $\mathrm{gD}(5-23)$ failed to induce detectable neutralising antibody titres even when combined with adjuvant $(p<0.0001)$.

\section{Anti-gD Antibody Response}

While no significant antibody titres were observed in
Table IV. Isotypic characteristics of anti-HSV-1 antibody titres in immunised $\mathrm{A} / \mathrm{J}$ mice as analysed by an indirect ELISA technique ${ }^{27}$ Serum samples pooled from 5 mice were harvested at the time of corneal infection with HSV-1

\begin{tabular}{lcccc}
\hline & \multicolumn{4}{c}{ Titres } \\
\cline { 2 - 5 } Groups of A/J mice & $\operatorname{IgG}_{1}$ & $\operatorname{IgG}_{2:}$ & $\operatorname{IgG}_{2 b}$ & $\operatorname{IgG}_{3}$ \\
\hline PBS. CFA & $<1 / 50$ & $<1 / 50$ & $<1 / 50$ & $<1 / 50$ \\
gD. CFA & $1 / 40()$ & $1 / 4(0)$ & $<1 / 800$ & $<1 / 50$ \\
gD(5-23). CFA & $<1 / 50$ & $1 / 50$ & $<1 / 50$ & $<1 / 50$ \\
gD(5-23)-KLH. CFA & $1 / 20()$ & $1 / 20()$ & $1 / 50$ & $<1 / 50$ \\
gD(5-23)-KLH. PBS & $1 / 20()$ & $1 / 200$ & $1 / 50$ & $<1 / 50$ \\
\hline
\end{tabular}

Abbreviations as in Table I.

the PBS,CFA group, mice injected with $\mathrm{gD}(5-23)$ coupled to $\mathrm{KLH}$ had detectable titres of $\operatorname{IgG}_{1}$ and $\mathrm{IgG}_{2 \mathrm{a}}$ and low titres of $\mathrm{IgG}_{2 \mathrm{~b}}$ anti-HSV antibodies $(p<0.05$ : Table IV).

\section{Latent Ganglionic Infection}

In trigeminal ganglia of mice injected with the control vehicle. latent virus infection was found in $100 \%$ of the specimens, while virus was recovered from $50 \%$ of $\mathrm{gD}$ injected mice and from $50-75 \%$ of mice injected with free or KLH-coupled $\mathrm{gD}(5-23)$ $(p<0.05 ;$ Table V).

\section{DISCUSSION}

Herpes simplex virus susceptible $A / J$ mice were injected subcutaneously with $\mathrm{gD}$ or $\mathrm{gD}(5-23)$ and the cornea subsequently challenged with HSV-1 $(F)$ in order to assess the protective efficacy against stromal keratitis and encephalitis. Our choice of this particular region of $\mathrm{gD}$, namely the $\mathrm{N}$-terminal

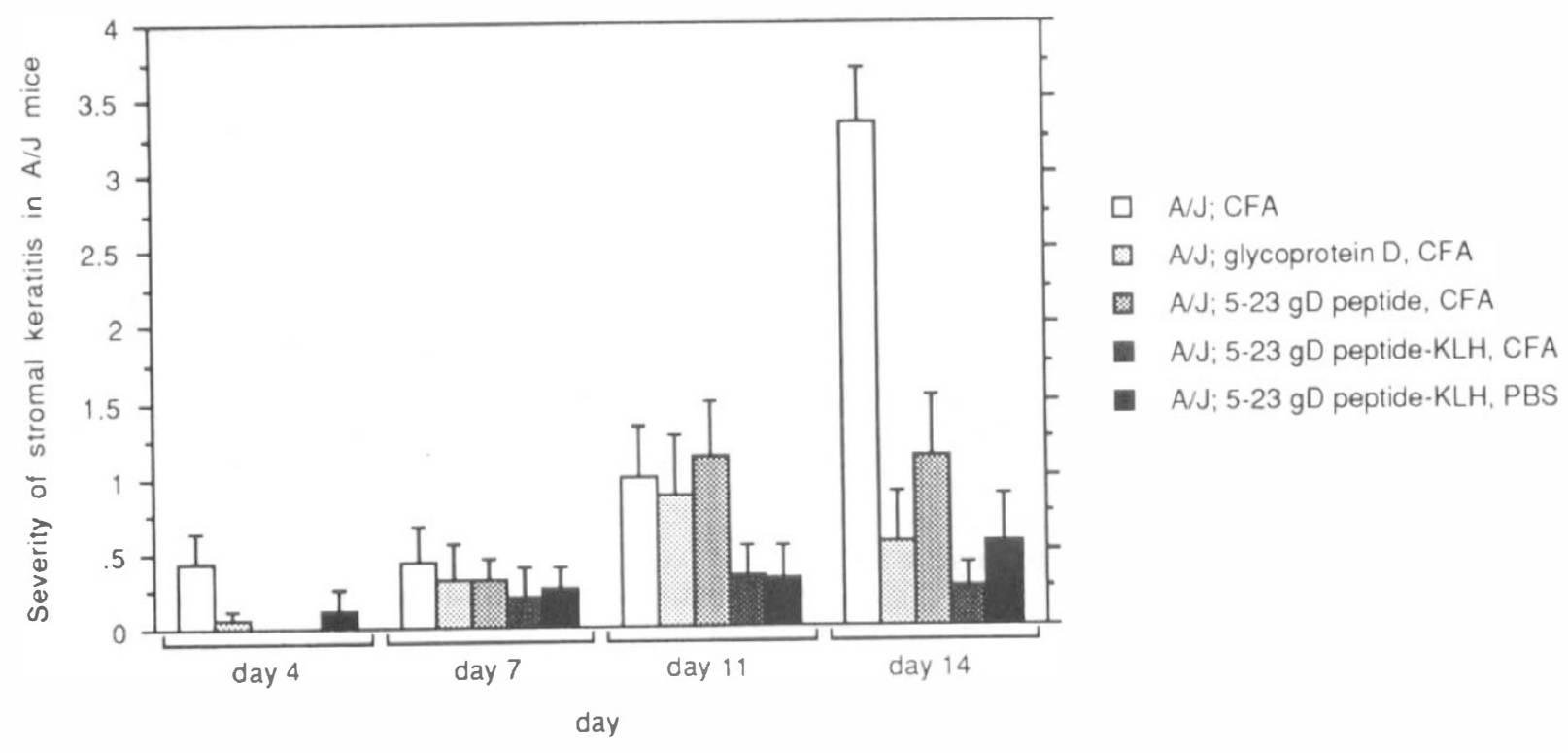

Fig. 1. A J J mice were immunised as described in Materials and Methods and as shown in Table I. Following inoculation with HSV-1 (F strain) animals were followed for 2 weeks for signs of stromal keratitis and scored on a scale of o) to 4+. The figure shows the severity of stromal keratitis $\pm S E M$ at different time points after inoculation. The results represent two experiments, each employing 8 mice per group. Abbreviations as in Table I. 


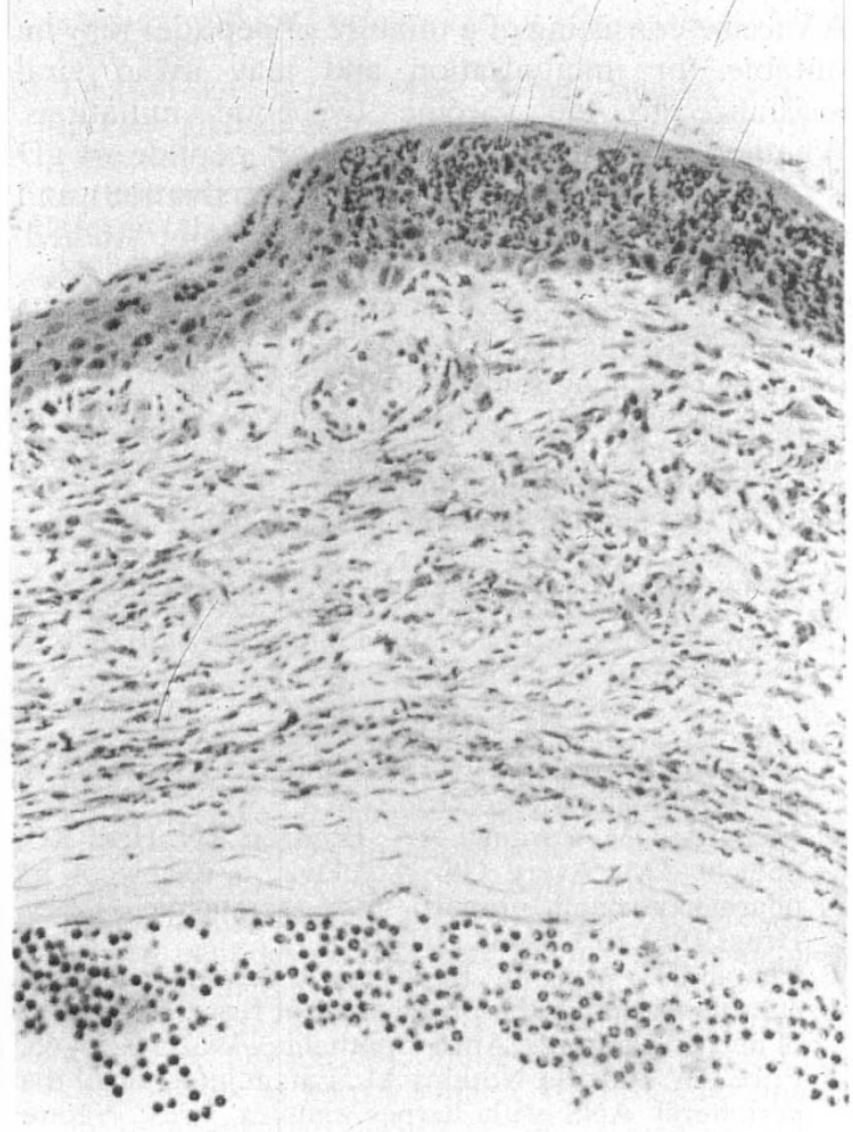

(a)

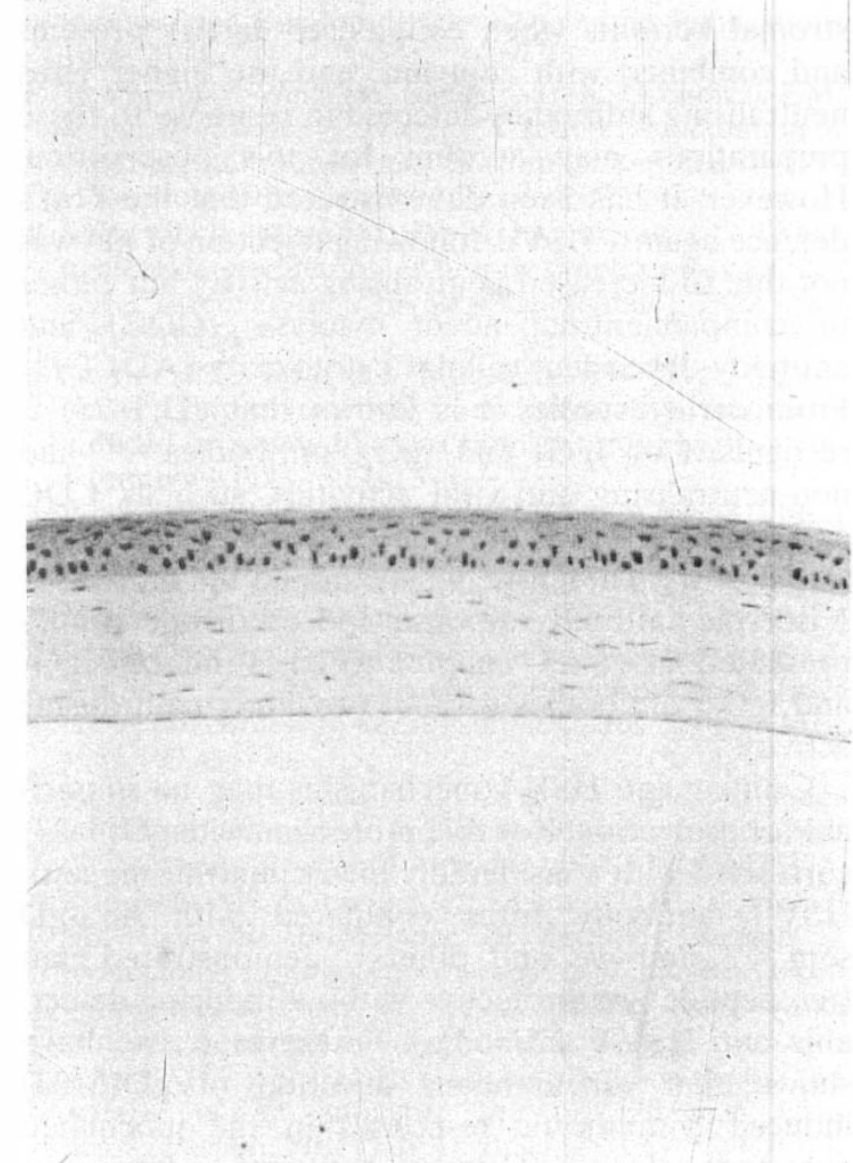

(b)

Fig. 2. Influence of subcutaneous immunisation with $\mathrm{gD}(5-23)$ coupled to keyhole limpet haemocyanin (KLH) and emulsified with complete Freund's adjuvant on the development of stromal keratitis in HSK-susceptible A/J mice. (a) Sham immunisation: marked corneal oedema, fibrovascular tissue with abundant neutrophils and mononuclear cells. (b) Immunisation with gD(5-23): normal appearance. Haematoxylin and eosin staining of cornea 14 days after corneal infection. Photomicrographs of representative sections (original magnification $\times 51$ ).

Table V. Effect of subcutaneous immunisation on the establishment of latent viral infection in trigeminal ganglia. The trigeminal ganglia were removed aseptically 14 days after HSV-1 infection, cocultured on Vero cells for 3 weeks, and assayed for cytopathological effects

\begin{tabular}{lc}
\hline Groups of A/J mice & No. of mice with ganglionic latency \\
\hline PBS, CFA & $6 / 6$ \\
Glycoprotein D, CFA & $4 / 8$ \\
gD(5-23), CFA & $6 / 8$ \\
gD(5-23)-KLH, CFA & $6 / 8$ \\
gD(5-23)-KLH, PBS & $4 / 8$ \\
\hline
\end{tabular}

Abbreviations as in Table I.

amino acid residues 5-23, was based on a previous publication which described the localisation of an antigenic determinant of $\mathrm{gD}$ contained within the $\mathrm{N}$ terminal amino acid residues $8-23$ of HSV-1 gD. This antigenic epitope was effective in protecting mice against an intraperitoneal challenge with HSV-1 when coupled to the protein carrier keyhole limpet haemocyanin. ${ }^{19}$ However, higher neutralising antibody titres were found in mice immunised with the
1-23 peptide sequence, but this had variable protective capacity. Therefore, we decided to evaluate $\mathrm{gD}(5-23)$ in a murine model of herpetic stromal keratitis. We chose the subcutaneous route of immunisation, since this had induced both humoral and cellular responses in previous studies. ${ }^{30}$

The results presented demonstrate that subcutaneous immunisation with $\mathrm{gD}(5-23)$ protects mice against blinding herpes stromal keratitis and lethal herpes encephalitis, and that protection is achieved at low dosages of peptide. ${ }^{31}$ The immunogenicity of the $\mathrm{N}$-terminal gD segment has been demonstrated by other studies. ${ }^{10,11}$ The use of a peptide for immunisation is encouraged by the fact that longterm protection against lethal encephalitis was achieved after a single peptide immunisation. ${ }^{32}$

The glycoprotein D peptide (5-23) stimulates neutralising antibodies which protect against herpetic keratitis, confirming previous findings with $\operatorname{gD}(1-23)$ peptide. ${ }^{15,19,26}$ Our data demonstrate that $\mathrm{gD}(5-23)$ confers better protection against herpes 
stromal keratitis when coupled to carrier proteins and combined with adjuvant, and the higher virus neutralising antibodies detected in response to these preparations may account for this observation. However, it has been demonstrated that the host's defence against HSV-1 following injection of $\mathrm{gD}$ was not due to increased neutralising activity but rather to complement-dependent cytolysis (CDC) and antibody-dependent cellular cytotoxicity (ADCC) ${ }^{18}$ From earlier studies it is known that $\mathrm{gD}(1-23)$ is recognised by $\operatorname{IgG}_{1}$ and $\operatorname{IgG}_{2 \mathrm{a}}$ antibodies, ${ }^{15.26}$ and non-neutralising anti-viral activities, such as CDC and ADCC, have been demonstrated for these isotypes. ${ }^{33,34}$ Therefore, we examined the anti-HSV1 isotypic antibody response. Indeed, in the studies presented, $\mathrm{gD}(5-23)$ coupled to $\mathrm{KLH}$ induced $\mathrm{IgG}_{1}$ and $\mathrm{IgG}_{2 \mathrm{a}}$ antibodies without providing neutralising activity.

Cellular anti-HSV-1 mechanisms may be important for protection. Reliable protection with $\mathrm{gD}(5-23)$ correlated with considerably lower neutralising antiHSV-1 antibody titres compared with anti-gD sera, ${ }^{15,17}$ and we and others ${ }^{35}$ demonstrated that free peptide was protective without inducing detectable anti-HSV-1 antibodies. Furthermore, we have shown that subcutaneous injection of $\mathrm{gD}(5-23)$ induced lymphocytic responses in the inoculated eye and spleen. ${ }^{36}$ Cellular anti-viral mechanisms were also suggested in previous studies that analysed the protective efficacy of HSV envelope glycoproteins ${ }^{17.30,37-39}$ or synthetic gD peptide. ${ }^{19,32}$

Further studies were undertaken to investigate whether immunisation with $\mathrm{gD}(5-23)$ prior to corneal infection influences the establishment of latent ganglionic infection and virus reactivation. Previous studies demonstrated that the adoptive transfer of virus neutralising or non-neutralising monoclonal anti-glycoprotein D antibodies ${ }^{9,11}$ failed to inhibit establishment of viral latency and epithelial keratitis completely, and the authors attributed this incomplete protection to the failure to induce cellular immunity. ${ }^{11}$ Both $\mathrm{gD}(5-23)$ and $\mathrm{gD}$ failed to provide complete protection against establishment of ganglionic latency in the present study, although cellular immunity was induced by immunising mice with $\mathrm{gD}(5-23)$. We can only speculate that ganglionic latency and epithelial keratitis might be affected through reduced primary infection, inhibition of viral replication, ${ }^{40}$ absorption and penetration, ${ }^{41}$ or impaired reactivation from latency.

Taken together. our data suggest that immunisation with a short peptide of gD of HSV-1 confers protection against herpes stromal keratitis by antiHSV-1 immune responses. Although the protection against acute keratitis was effective, the protection against ganglionic latency was incomplete, and this may result in recurrent keratitis over the long term.
A vaccine consisting of a mixture of peptides may be suitable for immunisation and may avoid viral resistance to the vaccine by point mutations. Whether immunisation with a short peptide of $\mathrm{gD}$ is sufficient to suppress virus reactivation and shedding and recurrent keratitis is yet to be studied.

This work was supported by grants from the National Institute of Health (No. EY(06)08 and EY05813) and the Deutsche Forschungsgemeinschaft (No. He 1877/1-1). The authors acknowledge the skilful technical assistance of Thomas M. Ihley, James E. Dutt and Dr Tong Zhen Zhao, and appreciate the helpful discussions they had with Dr Soon Jin Lee and Dr Sundararajan Jayaraman.

Key words: gD peptide. Glycoprotein. HS+V-1. Keratitis.

\section{REFERENCES}

1. Dawson C, Togni G. Herpes simplex eye infections. Surv Ophthalmol 1976;21:11-29.

2. Richards DM, Carmine AA, Brodgen RN, Heel RC, Speight TM, Avery GS. Acyclovir: a review of its pharmacodynamic properties and therapeutic efficacy. Drugs 1983;26:378-438.

3. Chapin $\mathrm{CH}$, Wong SC, Reapsome J. The value of tissue culture vaccine in the prophylaxis of recurrent attacks of herpetic keratitis. Am J Ophthalmol 1962;54:255-65.

4. Price RW, Katz BJ, Notkins AL. Latent infection of the peripheral ANS with herpes simplex virus. Nature 1975;257:686-8.

5. Meignier B. Vaccination against herpes simplex virus infections. In: Roizman B, Lopez C, editors. The herpes viruses. New York: Plenum Publishing, 1984:265-96.

6. Rawls WE. Herpes simplex viruses and their role in human cancer. In: Roizman B, Lopez C, editors. The herpes viruses. New York: Plenum Publishing, 1984:241-55.

7. Cremer KJ, Mackett M, Wohlenberg C, Notkins AL, Moss B. Vaccinia virus recombinant expressing herpes simplex virus type 1 glycoprotein $D$ prevents latent herpes in mice. Science 1985;228:737-40.

8. Green MT, Dunkel EC, Pavan-Langston D. Effect of immunisation and immunosuppression on induced ocular shedding and recovery of herpes simplex virus in infected rabbits. Exp Eye Res 1987;45:375-83.

9. Metcalf JF, Koga J, Chatterjee S, Whitley RJ. Passive immunization with monoclonal antibodies against herpes simplex virus glycoproteins protects mice against herpetic ocular disease. Curr Eye Res 1987;6:173-7.

10. Lausch RN, Staats H, Oakes JE, Cohen GH, Eisenberg RJ. Prevention of herpes keratitis by monoclonal antibodies for discontinuous and continuous epitopes on glycoprotein D. Invest Ophthalmol Vis Sci 1991;32:2735-40.

11. Inoue $Y$, Ohashi $Y$, Watanabe $H$, Manabe P. Protective effects of anti-glycoprotein D monoclonal antibodies in murine herpetic keratitis. Curr Eye Res 1992;11:53-60.

12. Cappel R. Comparison of humoral and cellular immune responses after immunisation with live, UV inactivated herpes simplex and a subunit vaccine and efficacy of these immunisations. Arch Virol 1976;52:29-36.

13. Carter CA, Hartley CE, Skinner GRB, Turner SP, Easty DL. Experimental ulcerative herpetic keratitis. IV. Preliminary observations on the efficacy of a herpes 
simplex subunit vaccine. $\mathrm{Br}$ J Ophthalmol 1981; 65:679-82.

14. Johnson DC, Ligas MW. Herpes simplex viruses lacking glycoprotein D are unable to inhibit virus penetration: quantitative evidence for virus-specific cell surface receptors. J Virol 1988;62:4605-12.

15. Cohen GH, Dietzschold B, Ponce de Leon M, Long D, Golub E, Varrichio A, et al. Localisation and synthesis of an antigenic determinant of herpes simplex virus glycoprotein $\mathrm{D}$ that stimulates the production of neutralising antibody. J Virol 1984;49:102-7.

16. Sandstrom IK, Foster CS, Wells PA, Knipe D, Caron L, Greene MI. Previous immunisation of mice with herpes simplex virus type-1 strain MP protects against secondary corneal infection. Clin Immunol Immunopathol 1986;40: 326-34.

17. Foster CS, Sandstrom IK, Wells PA, Thompson P, Daigle J, Opremcak EM. Immunomodulation of experimental murine herpes simplex keratitis. II. Glycoprotein D protection. Curr Eye Res 1988; 7:1051-61.

18. Inoue Y, Ohashi Y, Shimomura Y, Manabe R, Yamada $\mathrm{M}$, Ueda S, Kato S. Herpes simplex virus glycoprotein D: protective immunity against murine herpetic keratitis. Invest Ophthalmol Vis Sci 1990;31:411-8.

19. Eisenberg RJ, Cerini CP, Heilman CJ, Joseph AD, Dietzschold B, Golub E, et al. Synthetic glycoprotein D related peptides protect mice against herpes simplex virus challenge. J Virol 1985;56:1014-7.

20. Foster CS, Tsai Y, Monroe JG, Cambell RC, Cestari M, Knipe D, Greene MI. Genetic studies on murine susceptibility to herpes simplex keratitis. Clin Immunol Immunopathol 1986;40:313-25.

21. Bernatowicz MS, Matsueda GR. Preparation of peptide protein immunogens using $N$-succinimidyl bromacetate as a heterobifunctional crosslinking reagent. Anal Biochem 1986;155:95-102.

22. Ellman GL. Tissue sulfhydryl groups. Arch Biochem Biophys 1959;82:70-7.

23. Showalter SD, Zweig M, Hampar B. Monoclonal antibodies to herpes simplex virus type 1 proteins, including the immediate-early protein ICP-4. Infect Immun 1981;34:684-92.

24. Hampar B, Zweig M, Showalter D, Bladen SV, Riggs CW. Enzyme-linked immunosorbent assay for determination of antibodies against herpes simplex virus types 1 and 2 in human. J Clin Microbiol 1985; 21:496-500.

25. Zweig M, Showalter SD, Bladen SV, Heilman CJ Jr, Hampar B. Herpes simplex virus type 2 glycoprotein $\mathrm{gF}$ and type 1 glycoprotein $\mathrm{gC}$ have related antigenic determinants. J Virol 1983;47:185-92.

26. Eisenberg RJ, Ponce de Leon M, Pereira L, Long D, Cohen GH. Purification of glycoprotein gD of herpes simplex virus types 1 and 2 by use of monoclonal antibody. J Virol 1982;41:1099-104.

27. Nakamura RM, Voller A, Bidwell DE. Enzyme immunoassays: heterogeneous and homogeneous systems. In: Weir DM, editor. Handbook of experimental immunology. London: Blackwell Scientific Publications 1986: 21-4.

28. Thompson P, Wells PA, Sandstrom IK, Opremcak EM, Millin JA, Daigle A, Foster CS. Immunomodulation of experimental murine herpes simplex keratitis. I. UVHSV protection. Curr Eye Res 1988;7:1043-9.

29. Sainz de la Maza M, Wells PA, Foster CS. Cyclic nucleotide modulation of herpes simplex virus latency and reactivation. Invest Ophthalmol Vis Sci 1989;30:2154-9.

30. Schrier RD, Pizer LI, Moorhead JW. Type-specific delayed hypersensitivity and protective immunity induced by isolated herpes simplex virus glycoprotein. J Immunol 1983;130:1413-8.

31. Wells PA, Ihley TM, Foster CS. Immunisation with a synthetic HSV-1 glycoprotein D peptide protects mice from herpes simplex keratitis (HSK). Invest Ophthalmol Vis Sci 1988;29(Suppl):153.

32. Watari E, Dietzschold B, Szokan G, Heber-Katz E. A synthetic peptide induces long-term protection from lethal infection with herpes simplex virus 2. J Exp Med 1987;165:459-70.

33. Herlyn D, Koprowski H. IgG2a monoclonal antibodies inhibit human tumour growth through interaction with effector cells. Proc Natl Acad Sci USA 1982;79:4761-5.

34. Kaminski MS, Kitamura K, Maloney DC, Campbell MJ, Levy R. Importance of antibody isotype in monoclonal antiidiotype therapy of a murine B cell lymphoma: a study of the hybridoma class switch variants. J Immunol 1986;136:1123-30.

35. Atassi MZ, Webster RG. Localisation, synthesis, and activity of an antigenic site on influenza virus hemagglutinin. Proc Natl Acad Sci USA 1983;80:840-4.

36. Heiligenhaus A, Berra A, Dutt JE, Zhao TZ, Wells PA, Foster CS. T-zell vermittelter Schutz gegen HSV-1 keratitis durch Immunisierung mit synthetischen Peptid des glykoprotein D. Ophthalmologe 1994;91:in press.

37. Balachandran N, Bachetti S, Rawls WE. Protection against lethal challenge of BALB/c mice by passive transfer of monoclonal antibody to five glycoproteins of herpes simplex virus type 2. Infect Immun 1982;37:1132-7.

38. Rector JT, Lausch RN, Oakes JE. Use of monoclonal antibodies for analysis of antibody-dependent immunity to ocular herpes simplex virus type 1 infection. Infect Immun 1982;38:168-74.

39. Kümel G, Kaerner HC, Levine $M$, Schröder $\mathrm{CH}$, Glorioso JC. Passive immune protection by herpes simplex virus-specific monoclonal antibodies and monoclonal antibody-resistant mutants in pathogenicity. J Virol 1985;56:930-7.

40. Oakes JE, Lausch RN. Monoclonal antibodies suppress replication of herpes simplex virus type 1 in trigeminal ganglia. J Virol 1984;51:656-61.

41. Fuller AO, Spear PG. Specificities of monoclonal and polyclonal antibodies that inhibit absorption of herpes simplex virus to cells and lack of inhibition by potent neutralising antibodies. J Virol 1985;55:475-82. 